\title{
PALEOECOLOGIC IMPLICATIONS OF EPIBIONTS ON THE SILURIAN LICHID TRILOBITE ARCTINURUS
}

\author{
TETREAULT, Denis K., Dept. of Geological Sciences, Brock University, St. \\ Catharines, Ontario L2S 3A1, Canada
}

The Wenlockian lichid trilobite Arctinurus boltoni has been regarded as a classic example of a "snow-shoe" type adaptation. That is, the broad flat doublure has been interpreted as a resting surface, with well-developed terrace ridges serving as either sensory or frictional devices. New data from the Rochester Shale of western New York State indicate that this interpretation is incorrect. The discovery of the small, calcareous worm tube Cornulites on complete, articulated specimens of Arctinurus indicates that these trilobites seldom rested their doublure on the sediment surface. Apertures of all specimens of Comulites are oriented posteriorly, suggesting a rheophilic response to persistent water circulation patterns beneath the trilobite. The presence of suspension feeding organisms on the doublure also indicates that the water currents beneath the trilobite were free of suspended mud, so that Arctinurus may not have processed sediment in search of food.

Large specimens of Arctinurus also have numerous epibionts on the dorsal shield, including cyclostome bryozoans, brachiopods (Stegerhynchus) and Cornulites. The presence of these suspension feeders indicates that Arctinurus did not burrow or even partially cover itself with mud. The large number of epibionts on adult specimens of Arctinurus, including several age classes for Stegerhynchus, indicates that molting stopped or at least slowed greatly once a certain size was attained, and that these trilobites may have had fairly long life spans. 